\title{
PELATIHAN MICROSOF WORD DENGAN TEMA "CRATE AND EDITING TEKS” UNTUK MENINGKATKAN KINERJA GURU
}

\author{
Indra Kurniwan', Nur Alamsyah², Ambar Tri Hapsari ${ }^{3}$ \\ 1,2,3 Informatika, Fakultas Teknik dan Ilmu Komputer, \\ Universitas Indraprasta PGRI
}

\begin{abstract}
Abstrak
Salah satu penerapan teknologi informasi yang akan dikembangkan adalah penerapan Microsoft Office untuk pengembangan bahan ajar atau penulisan karya ilmiah. Microsoft mengembangkan salah satu program (software) yang dapat digunakan untuk pembuatan dokumen dan untuk mempresentasikan materi kepada audiens, termasuk di dalam proses pembelajaran di sekolah, yakni Microsoft Word. Program pengabdian masyarakat ini mengedepankan bagaimana proses pembinaan guru mengenai pemanfaatan aplikasi MS Word dalam pembuatan daftar isi, Daftar Tabel, Daftar Gambar, Daftar Pustaka dan Kutipan sebagai dasar tata cara penulisan karya ilmiah. Sebelum melakukan kegiatan pengabdian masyarakat, tim dosen melakukan riset tentang beberapa permasalahan yang dihadapi oleh mitra SD Negeri 1, dan SD Negeri 2 Setu. Metode yang dipakai adalah pengamatan secara langsung dan melakukan kegiatan wawancara. Dari hasil riset yang dilakukan oleh tim dosen, maka dipilih satu permasalahan yang dihadapi oleh para guru, yaitu kendala pembuatan bahan ajar dikarenakan kurangnya kemampuan penggunaan Microsoft Word. Solusi yang ditawarkan oleh tim dosen dalam melakukan pengabdian masyarakat ini adalah dengan cara memberikan pelatihan kepada guru di SD Negeri 1, dan SD Negeri 2 Setu, yang masih kesulitan dalam penggunaan Microsoft Word. Adanya pelatihan ini diharapkan dapat meningkatkan kemampuan tenaga pengajar dalam mengembangkan bahan ajar di sekolah
\end{abstract}

Keywords: Microsof Word, Crate And Editing, Kinerja Guru

\begin{abstract}
One application of information technology that will be developed is the application of Microsoft Office for the development of teaching materials or writing scientific papers. Microsoft develops one program (software) that can be used to create documents and to present material to audiences, including in the learning process in schools, namely Microsoft Word. The community service program promotes the process of teacher training regarding the utilization of MS Word applications in creating table of contents, List of Tables, List of Figures, Bibliography and Quotes as the basis for the procedure for writing scientific papers. Before conducting community service activities, the lecturer team conducted research on some of the problems faced by partner SD Negeri 1, and SD 2 Setu. The method used is direct observation and conducting interview activities. From the results of research conducted by the lecturer team, one problem faced by the teachers was chosen, namely the obstacle in making teaching materials due to the lack of ability to use Microsoft Word. The solution offered by the lecturer team in conducting community service is by providing training to teachers in SD 1, and SD 2 Setu, who are still having difficulties in using Microsoft Word. The existence of this training is expected to improve the ability of the teaching staff to develop teaching materials in schools
\end{abstract}

Keywords: Microsof Word, Crate And Editing, Teacher Performance

Correspondence author: Indra Kurniawan,inkur.master@gmail.com, Indonesia

This work is licensed under a $C C-B Y-N C$ 


\section{PENDAHULUAN}

Dengan semakin pesatnya perkembangan teknologi di berbagai bidang, maka dunia pendidikan harus menyesuaikan diri mengikuti perkembangan. Guru harus menyesuaikan diri mengikuti perkembangan. Guru sebagai ujung tombak dunia pendidikan, maka untuk menunjang pekerjaannya yang sekarang sudah menjadi profesi berdasarkan undang- undang guru dan dosen, semua guru harus belajar teknologi internet dan computer[1]. Salah satu penerapan teknologi informasi yang akan dikembangkan adalah penerapan Microsoft Office untuk pengembangan bahan ajar atau penulisan karya ilmiah [2]. Microsoft mengembangkan salah satu program (software) yang dapat digunakan untuk pembuatan dokumen dan untuk mempresentasikan materi kepada audiens, termasuk di dalam proses pembelajaran di sekolah, yakni Microsoft Word.

Microsoft Office Word merupakan sebuah program aplikasi pengolah kata (Word Processor) buatan Microsoft Corporation. Microsoft Office biasanya digunakan untuk membuat laporan, membuat dokumen berbentuk surat, membuat label surat, membuat tabel pada dokumen, dan masih nanyak lagi dokumen-dokumen lain yang bisa dibuat dengan menggunakan Microsoft Word. Microsoft Word dalam pengoperasiannya memiliki fungsi kontrol untuk memudahkan penggunanya dalam pengoperasian. Tombol-tombol shortcut sangat membantu karena lebih praktis dan cepat, jadi tidak perlu lagi susah- susah mengklik menu yang notabene membuang waktu. Guru sangatlah terbantu dengan penggunaan Microsoft Word ini.

Dari hasil observasi yang telah dilakukan oleh tim, didapat simpulan guru- guru yang belum secara maksimal menguasai penggunaan Microsoft Word. Guru harus menguasai memanfaatkan fungsi-fungsi pada yang berada pada toolbar Microsoft Word yang berfungsi untuk pengembangan bahan ajar di kelas, agar lebih menarik peserta didik dalam pembelajaran yang berlangsung.

\section{METODE PELAKSANAAN}

Metode yang akan dilakukan dalam kegiatan ini adalah melalui beberapa tahap: (a) Observasi langsung yakni pengabdi langsung datang ke lokasi pengabdian untuk memperoleh data. Hal ini kami lakukan pada saat menjelang maupun saat kegiatan berlangsung. Observasi berguna untuk mengetahui kondisi siswa-siswi dan guru-guru di SD Negeri 1, dan SD Negeri 2 Setu, dan menentukan instrumen apa yang diperlukan dalam pelatihan menggunakan Crate And Editing Teks pada Microsoft Word untuk guru-guru. Observasi sangat penting untuk mewujudkan kesuksesan kegiatan pengabdian masyarakat itu sendiri; (b) Workshop yaitu tim pengabdi melakukan pengenalan, tata cara dan simulasi dalam pelatihan Crate And Editing Teks pada Microsoft Word. Setelah guru-guru dilatih maka dilakukan simulasi untuk melihat dan mengevaluasi dari keadaan pada saat guru tersebut mengaplikasikanya.

\section{HASIL DAN PEMBAHASAN}

Pada tanggal 9 Agustus 2018 Kepala SD Negeri 1, dan SD Negeri 2 Setu, tim telah memberikan izin dilaksanakannya kegiatan pengabdian masyarakat, dan pelaksanaan pelatihan dimulai pada tanggal 2 November 2018 sampai tangal 27 November 2018 kegiatan pengabdian masyarakat dengan tema Crate And Editing 
Teks Untuk Meningkatkan Kinerja Guru. Setelah mendapatkan izin dari pihak sekolah, kemudian kami mulai persiapan dan membuat modul materi pelatihan sesuai dengan jumlah peserta yang akan datang mengikuti pelatihan. Dari data yang diperoleh jumlah peserta yang akan mengikuti pelatihan ini sekitar 20 guru SD Negeri 1, dan SD Negeri 2 Setu.

\section{Pelaksanaan Abdimas Crate And Editing Teks di SD Negeri 1 Setu}

Materi yang kami berikan adalah materi tentang pembuatan daftar isi, Daftar Tabel, Daftar Gambar, Daftar Pustaka dan Kutipan sebagai dasar tata cara penulisan karya ilmiah animasi, menggunakan Microsoft Word. Kegiatan pelatihan ini dilaksanakan di SD Negeri 1 sebanyak 20 peserta yang dilakukan selama 4 x pertemuan. Mereka sangat antusias mengikuti pelatihan Microsoft word Crate And Editing Teks dari awal hingga akhir. Pelaksanaan Abdimas berjalan dengan lancar. Hal ini terbukti, dalam waktu yang relatif singkat peserta dapat membuat animasi dan desain yang menarik sebagai bahan ajar pada mata pelajaran masing-masing. Berikut gambar kegitan masing masing pertemuan yang dilakukan.

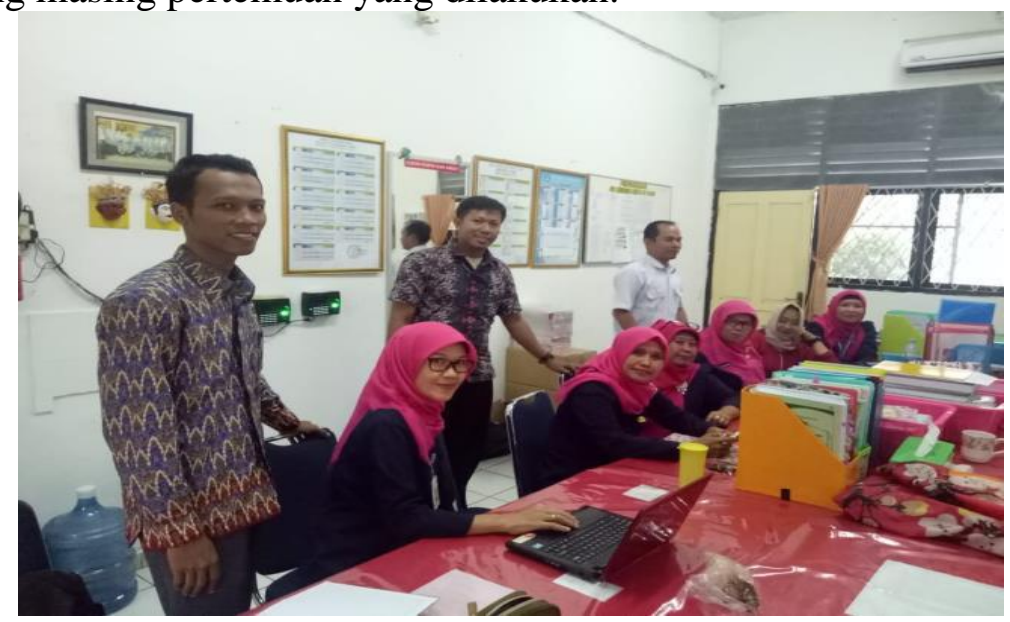

Gambar 1. Kegiatan Abdimas Pertemuan 1 SD Negeri 1 Setu

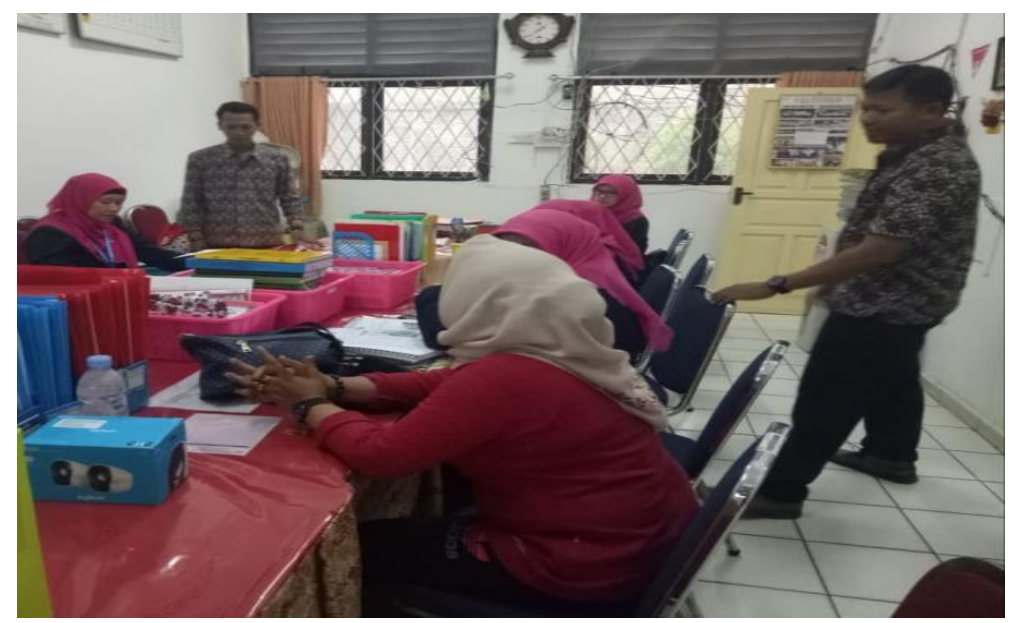

Gambar 2. Kegiatan Abdimas Pertemuan 2 SD Negeri 1 Setu 


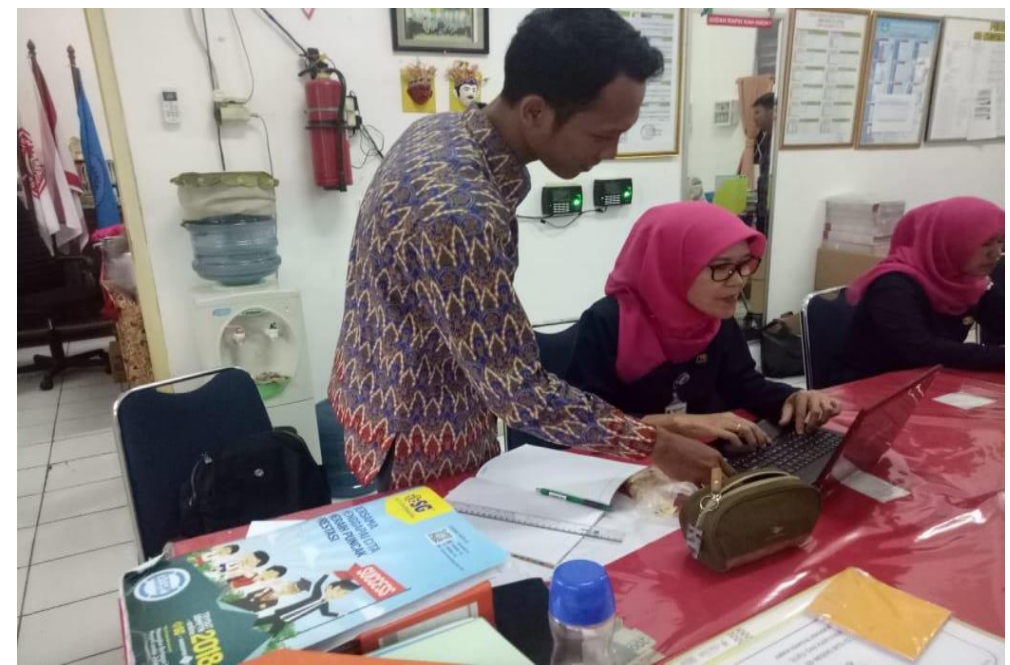

Gambar 3. Kegiatan Abdimas Pertemuan 3 SD Negeri 1 Setu

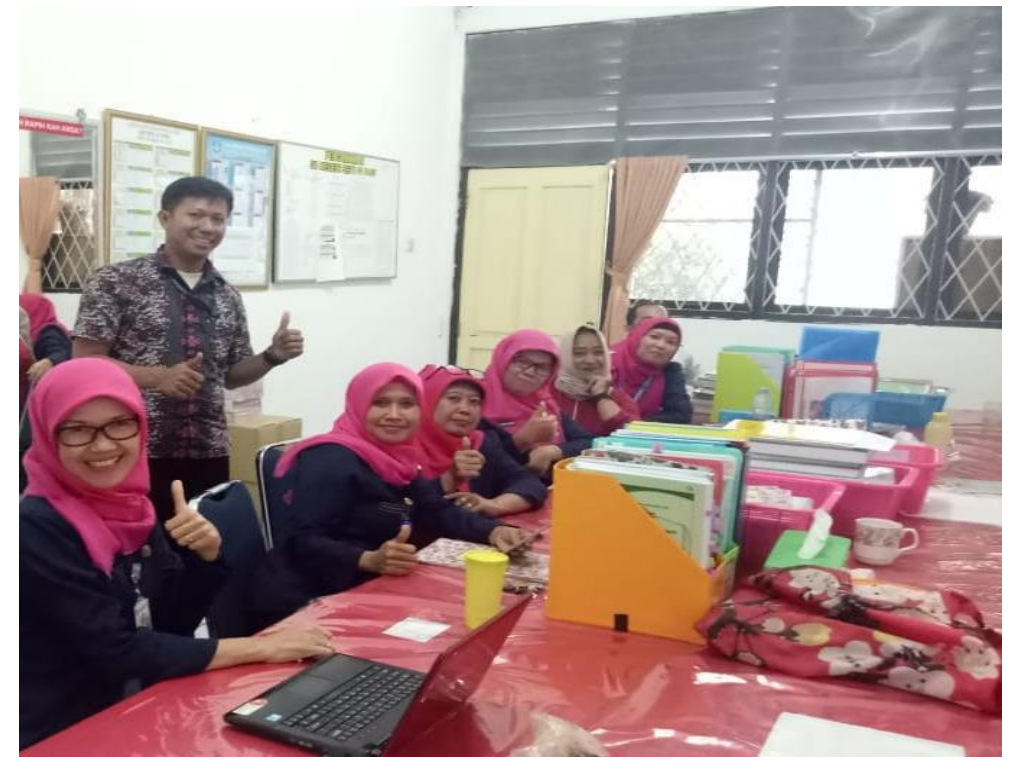

Gambar 4. Kegiatan Abdimas Pertemuan 4 SD Negeri 1 Setu

\section{Pelaksanaan Abdimas Crate And Editing Teks di SD Negeri 2 Setu}

Materi yang kami berikan adalah materi tentang pembuatan daftar isi, Daftar Tabel, Daftar Gambar, Daftar Pustaka dan Kutipan sebagai dasar tata cara penulisan karya ilmiah animasi, menggunakan Microsoft Word. Kegiatan pelatihan ini dilaksanakan di SD Negeri 2 sebanyak 20 peserta. Yang dilakukan selama $4 \mathrm{x}$ pertemuan. Mereka sangat antusias mengikuti pelatihan Microsoft word Crate And Editing Teks dari awal hingga akhir, pelaksanaan Abdimas berjalan dengan lancar, terbukti dalam waktu yang relatif singkat peserta dapat membuat animasi dan desain yang menarik sebagai bahan ajar pada mata pelajaran masing- masing. Berikut gambar kegitan masing masing pertemuan yang dilakukan. 


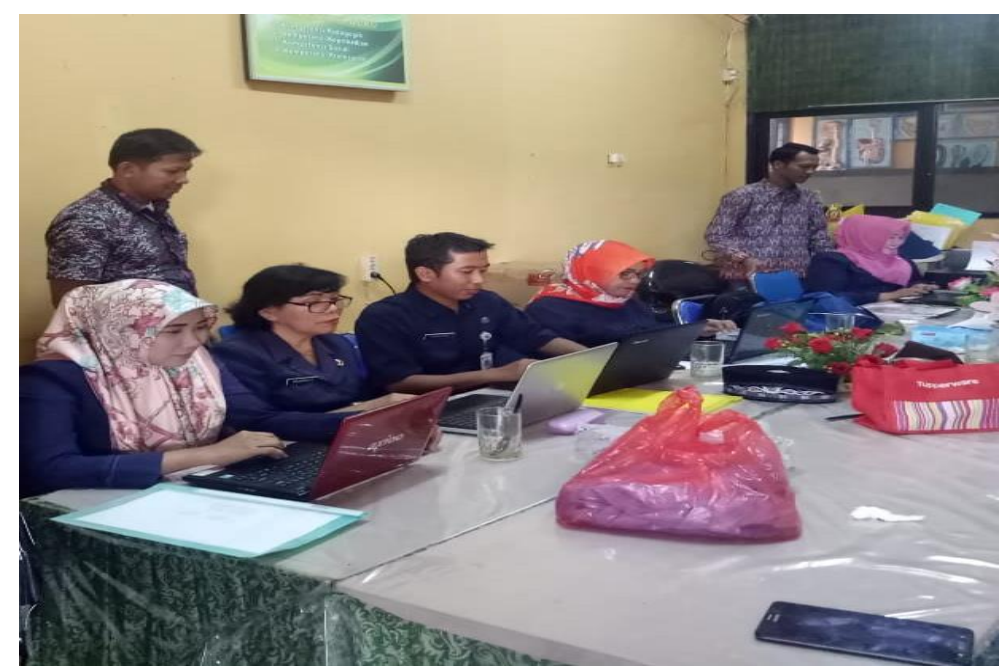

Gambar 5. Kegiatan Abdimas Pertemuan 1 SD Negeri 2 Setu

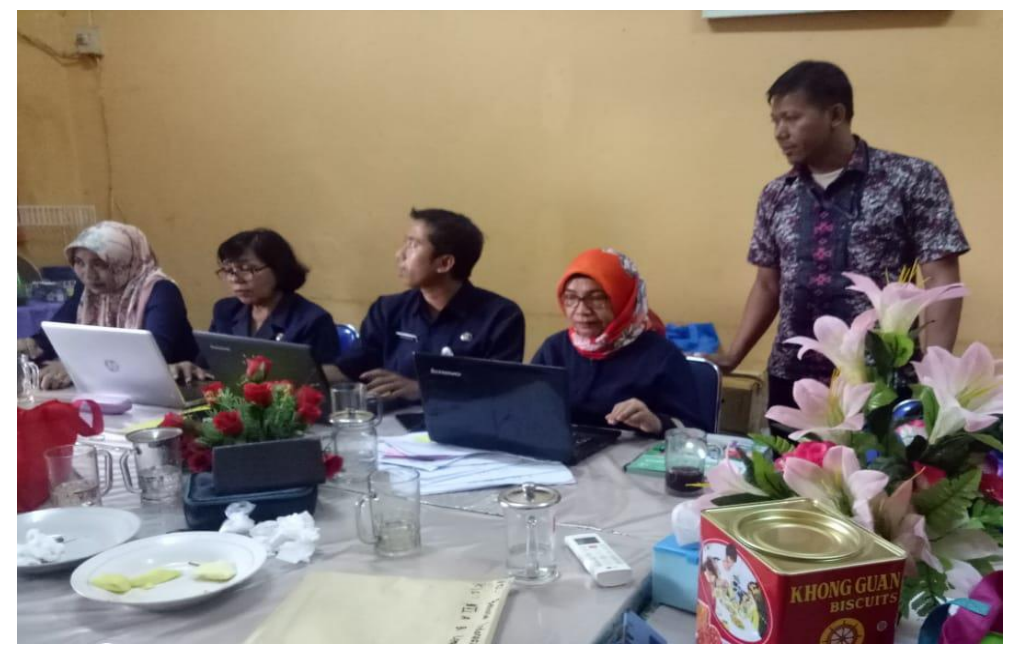

Gambar 6. Kegiatan Abdimas Pertemuan 2 SD Negeri 2 Setu

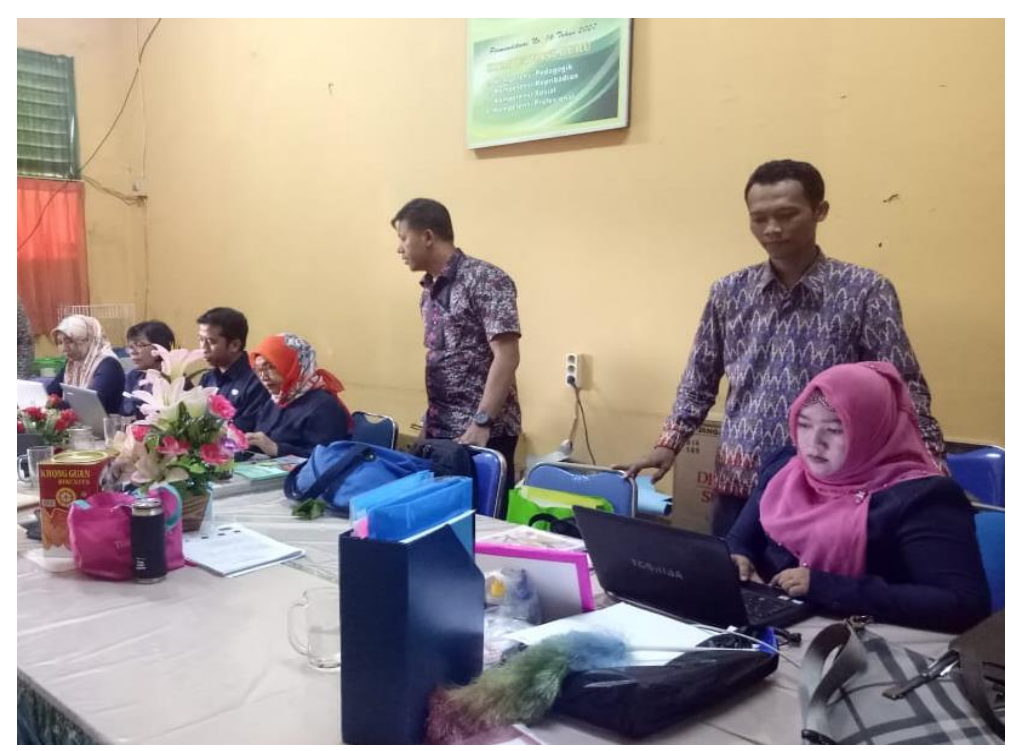

Gambar 7. Kegiatan Abdimas Pertemuan 3 SD Negeri 2 Setu 


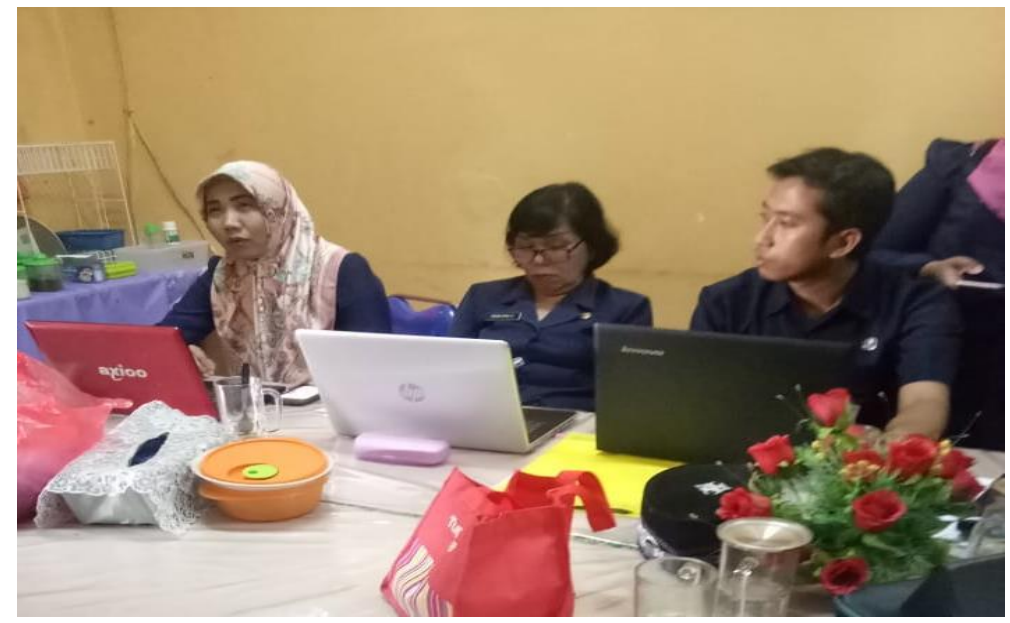

Gambar 8. Kegiatan Abdimas Pertemuan 4 SD Negeri 2 Setu

Implementasi Media Pembelajaran Berbasis Multimedia Presentasi Guru di Sekolah Dasaar Negeri, dilakukan oleh Tim yang beranggota 3 orang dari Universitas Indraprasta PGRI. Tempat pelatihan dilaksanakan di ruang multimedia SD Negeri 1 Setu, dan ruang Multimedia di SD Negeri 2 Setu. Berdasarkan pelatihan yang telah dilaksanakan diperoleh hasil sebagai berikut: (a) Guru telah mampu membuat desain yang menarik menggunakan Microsoft Word untuk keperluan membuat daftar isi, daftar tabel, daftar gambar, daftar pustaka dan kutipan sebagai dasar tata cara penulisan karya ilmiah, sehingga kinerja guru meningkat dalam membuat karya ilmiah. (b) Guru memiliki kemampuan cara mengedit gambar dan dengan menggunakan Microsoft Word sehingga guru lebih mudah dalam menjalankan tugas dan kewajiban dalam penulisan karya ilmiah. (c) Guru mampu menggunakan Microsoft Word "Creat and Edit" dalam penulisan ilmiah dan berbagai tulisan lainnya.

\section{SIMPULAN}

Pelatihan Microsof Word Dengan Tema "Crate And Editing Teks Untuk Meningkatkan Kinerja Guru SD Negeri 1, dan SD Negeri 2 Setu. Berdasarkan hasil umpan balik didapatkan informasi bahwa kegiatan ini sangat relevan dengan kebutuhan para peserta. Mereka merasa mendapat wawasan dan skill yang aplikatif dan bermanfaat. Selain itu mereka juga merasa senang dengan teknik dan metode pelatihan yang diterapkan selama pelatihan. Kemampuan yang dilatihkan dan dimiliki peserta sangat berguna sekali untuk menunjang sistem kinerja guru di sekolah

\section{DAFTAR PUSTAKA}

Boeykens, S., Falcó, C. A., Ruiz Vázquez, M. M., \& Tortorelli, M. D. C. (2015). Evaluation of an Organic Waste Composting Device to Household Treatment. Journal of Sustainable Development of Energy, Water and Environment Systems, 3(3), 245-255.

Papadopoulos, A. E., Stylianou, M. A., Michalopoulos, C. P., Moustakas, K. G., Hapeshis, K. M., Vogiatzidaki, E. E. I., \& Loizidou, M. D. (2009). Performance of a new household composter during in-home testing. Waste management, 29(1), 204-213. 
